\title{
Проблемы формулирования и разграничения презумпций и фикций в трудовом праве
}

\author{
О. Е. Зацепина \\ Алтайский государственный университет \\ пр.Ленина, 61, 656049, Барнаул, Россия. E-mail:zatsepina.olesya@yandex.ru
}

Статья посвящена презумпциям и фикциям в трудовом праве как средствам юридической техники, вопросам их формулирования и разграничения. Установлено, что законодатель в рассматриваемой отрасли права (как и в других его отраслях) для закрепления презумпции в норме права использует слова, отражающие сущность и являющиеся распространенной формой выражения правовой фикции, что способствуетсмешению этих средств юридической техники. Но главным критерием разграничения презумпций и фикций является не словесная форма их выражения, а наличие или отсутствие степени вероятности. Выявлено, что возможность закрепления правовой фикции не только с помощью характерных слов, но и без них привела к существованию позиции, ставящей под сомнение использование в трудовом праве правовых фикций как особых средств юридической техники. Доказана несостоятельность такой точки зрения посредством объяснения указанной возможности существованием двух способов закрепления правовой фикции: прямо го и косвенного, и установлено, что фикции как средства юридической техники в рассматриваемой отрасли права являются весьма распространенным явлением. Сделан вывод о том, что для правильного выявления исследуемых правовых явлений в правовых нормах и их разграничения между собой следует помнить, что наличие или отсутствие в конкретной норме права презумпции или фикции как средств юридической техники определяется не наличием или отсутствием в ней характерных слов, а ее смыслом и юридическим значением, которым она обладает согласно воле законодателя.

Ключевые слова: правовая презумпция, правовая фикция, трудовое право, словесная форма выражения.

\section{Framing and Differentiation of Presumptions and Fictions in Labor Law}

\author{
O. E. Zatsepina \\ Altai State University \\ Lenin St. 61, 656049, Barnaul, Russia.E-mail:zatsepina.olesya@yandex.ru
}

\begin{abstract}
The article discusses presumptions and fictions in labor law as means of legal technique, as well as issues of their framing and differentiation. It has been established that in the branch of law under consideration(as well as in its other branches) the legislator uses words which reflect the nature and which are a common form of expression of legal fiction to entrench the presumption in the rule of law, which contributes to the confusion of these means of legal technique. Still the main criterion for distinguishing between presumptions and fictions is not the verbal form of their expression, but the presence or absence of a degree of probability. It has been found out that the possibility of entrenching the legal fiction with the help of both typical words and without them led to the point of view questioning the use of legal fictions in labor law as special means of legal technique. The author proves the inconsistency of this point of view by explaining this possibility by the existence of two ways of entrenching the legal fiction: direct and indirect, and it is established that fictions as means of legal technique in the considered branch of law are a very common phenomenon. It is concluded that for correct identification of the above legal phenomena in legal rules and differentiation between them, one should remember that the presence or absence of presumption or fiction in a specific rule of law as means of legal technique is not determined by the presence or absence of typical words, but rather by the meaning and legal value of this rule of law which it has according to the discretion of the legislator.
\end{abstract}

Key words: legal presumption, legal fiction, labor law, verbal expression.

В трудовом праве, как и во многих других отраслях российского права, существует проблема разграничения правовых презумпций и фикций как средств юридической техники.

Наличие указанной проблемы в различных отраслях права обусловлено отсутствием единыхцелостных общепризнанных теорий рассматриваемыхправовых явлений на общеправовом уровне. 
Но данный вопрос не является предметом настоящей статьи, в ней мы рассмотрим специфику его преломления именно в трудовом праве.

Начнем с определений указанных понятий. В научной литературе их существует бесчисленное количество в связи с различными взглядами исследователей на сущность, основные признаки и свойства этих правовых явлений. Мы, в свою очередь, предлагаем следующие авторские определения:

Правовая презумпция - это средство юридической техники, с помощью которого в правовых нормах закрепляется вероятное предположение, которое считается истинным, пока не доказаны факты, его опровергающие, и применяемое в целях охраны различных интересов (личности, общества и государства).

Правовая фикция - это средство юридической техники, с помощью которого в правовых нормах закрепляется заведомо ложное неопровержимое положение, определенным образом деформирующее действительность в целях охраны различных интересов (личности, общества и государства).

Таким образом, полагаем, что основным отличием презумпций и фикций друг от друга выступает наличие или отсутствие какойлибо степени вероятности.

Однако вопрос их разграничения осложняет словесная форма выражения, которую выбирает законодатель при создании трудоправовых норм, содержащих презумпции и (или) фикции.

Например, О.В. Танимов [Танимов 2016: 251] полагает, что положение ч. 3 ст. 71 ТК РФ, согласно которому «если срок испытания истек, а работник продолжает работу, то он считается выдержавшим испытание и последующее расторжение трудового договора допускается только на общих основаниях» представляет собой фикцию. На такую мысль указанного автора наталкивает слово «считается», используемое законодателем в данной статье, которое является распространенной формой выражения именно правовой фикции.

Однако презумпции тоже могут быть закреплены в правовых нормах с помощью этого слова. Ярким примером тому служит презумпция невиновности, закрепленная в ч. 1 ст. 14 УПК РФ с помощью слова «считается» («обвиняемый считается невиновным, пока его виновность в совершении преступления не будет доказана...»), а не «предполагается», что, на наш взгляд, было бы более прави льно и логично, так как соответствовало бы предположительному и опровержимому характеру указанного положения этой статьи.

Поэтому еще раз подчеркнем, что главным критерием разграничения презумпций и фикций выступает не словесная форма их выражения, а наличие или отсутствие какой-либостепени вероятности.

Исходя из этого, представляется обоснованной позиция С.Ю. Головиной [Головина 2010: 114-115], которая относит анализируемое правовое положение не к фикциям, а к презумпциям, поскольку оно представляет собой высоковероятное (так как фактически работник в этом случае, скорее всего, действительно выдержал испытание) предположение о том, что работник выдержал испытание. Однако мнение указанного автора о том, что данную презумпцию может опровергнуть работодатель, до истечения испытательного срока расторгнув трудовой договор с работником как с не выдержавшим испытание в случае неудовлетворительного результата этого испытания согласно ч. 1 ст. 71 ТК РФ, не представляется правильным, поскольку рассматриваемая презумпция применяется только после истечения испытательного срока. Поэтому полагаем, что данная презумпция является неопровержимой, так как после окончания испытательного срока расторжение трудового договора допускается только на общих основаниях, то есть, даже если работник на самом деле все-таки не выдержал испытания, это уже не будет иметь никакого юридического значения.

Положение ч. 8 ст. 48 ТК РФ, устанавливающее, что, если работодатели не представили в надлежащий федеральный орган исполнительной власти «в течение 30 календарных дней со дня официального опубликования предложения о присоединении к федеральному отраслевому соглашению мотивированный отказ присоединиться к нему, то соглашение считается распространенным на этих работодателей со дня официального опубликования этого предложения» В.Ю. Чуфаров [Чуфаров 2010: 185] относит к фикциям, а С.Ю. Головина [Головина 2010: 114-115] обоснованно утверждает, что в данном случае презюмируется согласие работодателей на присоединение к соглашению.

Действительно рассматриваемое положение обладает определенной степенью вероятности, поэтому является правовой презумпцией, применяется только после истечения указанного срока и уже не может быть опровергнуто работодателями посредством направления мотивированного отказа, поэтому неопровержимо. Но фикция в данной норме также содержится, дополняя действие указанной правовой презумпции.

По справедливому наблюдению О.В. Танимова [Танимов 2016: 251], посредством фикции в данном случае определяется день, с которого соглашение считается распространенным на работодателей. Таким днем согласно ч. 8 ст. 48 ТК РФ признается день официального опубликования предложения о присоединении к соглашению, что является исключением из правила, установленного ч. 1 ст. 48 ТК РФ, в соответствии с которым «соглашение вступает в силу со дня его подписания сторонами либо со дня, установленного соглашением», и не соответствует действительности.

Полагаем, что, во избежание смешения рассматриваемых средств юридической техники, не следует формулировать презумпции (в том числе неопровержимые, для большей ясности в некоторых случаях можно прямо указывать на запрет их опровержения) с помощью слов «считается», «признается» и подобных им, так как они соответствуют сущности именно правовой фикции, указывают на ее ложность и императивность.

Следует отметить, что законодатель использует указанные слова для закрепления правовых презумпций не только в трудовом праве, но и в других его отраслях. Например, в соответствии с презумпцией отцовства (ч. 2 ст. 48 СК РФ) «отцом ребенка, родившегося от лиц, состоящих в браке, либо в течение трехсот дней с момента расторжения брака, признания его недействительным или с момента смерти супруга матери, признается супруг матери (бывший супруг), если не доказано иное».

А возможность закрепления трудоправовых фикций не только с помощью названных выше характерных слов, но и без них привела к существованию позиции, ставящей под сомнение использование в трудовом праве правовых фикций как элементов юридической техники.

Так, Д.А. Смирнов [Смирнов 2017: 54, 55] утверждает, что в этой отрасли права, в отличие от иных отраслей, фикции как особые глубинные приемы юридической техники не применяются, а зависят лишь от способа формулирования соответствующих правовых норм. К такому выводу данный автор приходит в связи с примерами трудоправовых фикций, приведенными О.В. Танимовым [Танимов 2016: 251], каждая из которых формулируется с помощью слова «считается» (днем окончания срока считается ближайший рабочий день, следующий за нерабочим днем, на который приходится последний день срока (ст. 14 ТК РФ), аннулированный трудовой договор считается незаключенным (ч. 4 ст. 61 ТК РФ), фактическое допущение к работе уполномоченным на это лицом считается заключением трудового договора (ст. 67 ТК РФ), при предоставлении неиспользованных отпусков с последующим увольнением днем увольнения считается последний день отпуска (ч. 2 ст. 127 ТК РФ), работник считается не имеющим дисциплинарного взыскания, если в течение года

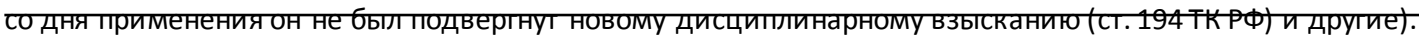

Юрислингвистика, 14, 2019 
Свою позицию Д.А. Смирнов аргументирует тем, что, если переформулировать ч. 6 ст. 80 ТК РФ, регламентирующую расторжение трудового договора по инициативе работника (по собственному желанию), в которой, по его мнению, отсутствует фикция, вместо положения «если по истечении срока предупреждения об увольнении трудовой договор не был расторгнут и работник не настаивает на увольнении, то действие трудового договора продолжается» закрепив, что в указанном случае заявление работника об увольнении по собственному желанию считается неподанным, то данная норма будет содержать фикцию, а если, наоборот, представить ч. 1 ст. 67 ТК РФ в следующей редакции: «трудовой договор заключается в двух формах: письменной и конклюдентной (в виде фактического допущения либо признания отношений, возникших на основании гражданско-правового договора, трудовыми)» [Смирнов 2017: 54], то она не будет содержать фикцию.

Представляется, что данная точка зрения не соответствует правовой действительности, так как наличие или отсутствие фикции в определенной норме права не определяется наличием или отсутствием слова «считается» и подобных слов.

В приведенных Д.А. Смирновым примерах фактически речь идет о двух способах закрепления правовых фикций: прямом и косвенном. Большинство фикций в трудовом праве закреплено прямым способом с помощью слова "считается», но существуют и косвенные трудоправовые фикции, которые выводятся из правовых норм путем их толкования. Одна из таких косвенных фикций содержится в положении ч. 6 ст. 80 ТК РФ, анализируемом Д.А. Смирновым. Предложенное им переформулирование этой статьи превращает косвенную фикцию в прямую, а изменение ч. 1 ст. 67 ТК РФ - наоборот, делает из прямой фикции косвенную.

В подтверждение этого можно привести пример правовой фикции, приведенный М.В. Лушниковой и А.М. Лушниковым (который Д.А. Смирнов [Смирнов 2017: 54] также цитирует в своей статье): «прекращение деятельности филиала, представительства или иного обособленного структурного подразделения организации, расположенных в другой местности, признается ликвидацией организации в целях расторжения трудового договора по инициативе работодателя» (ч. 4 ст. 81 ТК РФ), то есть авторы [Лушникова, Лушников 2006: 506] указывают на фикцию, закрепленную прямым способом с помощью слова «признается», хотя согласно ч. 4 ст. 81 ТК РФ «расторжение трудовых договоров с работниками обособленного структурного подразделения организации, расположенного в другой местности и прекратившего деятельность, производится по правилам, предусмотренным для случаев ликвидации организации», то есть данная фикция закреплена законодателем косвенным способом, при этом ее наличие в рассматриваемой правовой норме Д.А. Смирнов не оспаривает.

Косвенными трудоправовыми фикциями также, например, являются: фикция, приравнивающая усыновление к рождению ребенка (согласно ч. 4 ст. 257 ТК РФ женщине, усыновившей ребенка, может быть предоставлен отпуск по беременности и родам содня усыновления), фикция, позволяющая по заявлению работника изменить формулировку незаконного основания увольнения на увольнение по собственному желанию (ч. 4 ст. 394 ТК РФ), фикция, устанавливающая обязанность суда при признании увольнения незаконным и истечении на время рассмотрения спора судом срока трудового договора изменить формулировку увольнения на увольнение по истечении срока трудового договора (ч. 6 ст. 394 ТК РФ) и другие.

Исходя из этого, точка зрения Д.А. Смирнова, согласно которой в трудовом праве «фикция как особый глубинный приём юридической техники не нашла своего применения» [Смирнов 2017: 55] представляется неубедительной . Наоборот, фикции как средства юридической техники в этой отрасли права являются весьма распространенным явлением.

Таким образом, для правильного выявления исследуемых правовых явлений в правовых нормах и их разграничения между собой следует помнить, что наличие или отсутствие в конкретной норме права презумпции или фикции как средств юридической техники определяется не наличием или отсутствием в ней характерных слов, а ее смыслом и юридическим значением, которым она обладает согласно воле законодателя.

\section{Литература}

1. Головина С.Ю. Презумпции в трудовом праве / Юридическая техника. - 2010. - № 4. - С. 114-118.

2. Лушникова М.В., Лушников А.М. Очерки теории трудового права. СПб., 2006.

3. Смирнов Д.А. Проблема фикций в трудовом праве: реальная или надуманная? / Вестник ЯрГУ. Серия Гуманитарные науки. - 2017. - № 2 (40). - С. 51-55.

4. Танимов О.В. Теория юридических фикций: монография / отв. ред. д.ю.н., проф. Т.В. Кашанина. М., 2016.

5. Чуфаров В.Ю. Нетипичные нормативные предписания в трудовом праве: дис.... канд. юрид. наук: 12.00.05. Екатеринбург, 2010.

\section{References}

1. Golovina, S.Yu. (2010). Presumptions in labor law. [Prezumptsii v trudovom prave]. Legal technique, 4, 114-118 (in Russian).

2. Lushnikova, M.V., Lushnikov, A.M. (2006). Essays on the theory of labor law. [Ocherki teorii trudovogo prava]. St. Peterburg (in Russian).

3. Smirnov, D.A. (2017). The fiction problem in labor law: real or far-fetched? [Problema fiktsiy $v$ trudovom prave: real'naya ili nadumannaya?]. Vestnik of Yaroslavl State University. Series Humanities, 2 (40), $51-55$ (in Russian).

4. Tanimov, O.V. (2016). Theory of legal fictions: monograph / ed. [Teoriya yuridicheskikh fiktsiy]: a monograph / ex. ed. Doctor of Law, prof T.V. Kashanina. Moscow (in Russian).

5. Chufarov, V.Yu. (2010). [Netipichnyye normativnyye predpisaniya v trudovom prave]: Atypical normative precepts in labor law: dis .... cand. legal sciences: 12.00 .05 . Ekaterinburg (in Russian).

\section{Citation:}

Зацепина, О.Е. Проблемы формулирования и разграничения презумпций и фикций в трудовом праве. // Юрислингвистика. - 2019. - 14.- С. 11-13.

Zatsepina, O. E. (2019). Framing and Differentiation of Presumptions and Fictions in Labor Law. Legal Linguistics, 14,11-13.

(cc) EY This work is licensed under a Creative Commons Attribution 4.0. License 